\title{
Biophysical Evaluation of the Vadose Zone at a Landfill Site in the Niger Delta, Nigeria
}

\author{
Akaha C. Tse ${ }^{*}$, Lucky 0. Odokuma² \\ ${ }^{1}$ Department of Geology, University of Port Harcourt, Port Harcourt, Nigeria \\ ${ }^{2}$ Department of Microbiology, University of Port Harcourt, Port Harcourt, Nigeria \\ Email: *akaha.tse@uniport.edu.ng
}

Received 20 March 2016; accepted 19 April 2016; published 22 April 2016

Copyright (C) 2016 by authors and Scientific Research Publishing Inc.

This work is licensed under the Creative Commons Attribution International License (CC BY). http://creativecommons.org/licenses/by/4.0/

(c) (i) Open Access

\section{Abstract}

The vadose zone of a landfill site proposed as an integrated waste management facility was evaluated based on geohydrological, chemical and microbiological characteristics of the groundwater and underlying soil. These data were also used to assess the attenuation capacity of the zone by the use of microbial degradation test of some major constituents including fatty acids, organic nitrogen and chloride of the leachate for a 28-day period. The main soil type in vadose zone consisted of brownish clayey sand of low permeability. The depth to water table which is equal to the thickness of the vadose zone varied from $8-13 \mathrm{~m}$. Groundwater flowed with a hydraulic gradient of approximately $4.0 \times 10^{-3}$ and a pore velocity of $1.6 \times 10^{-3} \mathrm{~cm} / \mathrm{sec}$. The results of the biodegradation tests showed that the major constituents of the leachate such as ammonia/organic nitrogen, phosphate and organic carbon were completely degraded within 28 days. The population of aerobic bacteria within the $6 \mathrm{~m}$ soil depth was sufficient to bring about over $0.05 \%$ organic carbon removal. The soil characteristics in the vadose zone are very favourable for the occurrence of natural attenuation. The potential natural attenuation capacity of the vadose zone is therefore classified as moderate to high.

\section{Keywords}

Attenuation, Biodegradation, Biophysical, Landfill, Vadose Zone

\section{Introduction}

Landfills are covered or uncovered (open dump) waste receiving pits. They fall into different categories depending on the planning, design, construction, operation and closure as follows:

\footnotetext{
"Corresponding author.
}

How to cite this paper: Tse, A.C. and Odokuma, L.O. (2016) Biophysical Evaluation of the Vadose Zone at a Landfill Site in the Niger Delta, Nigeria. Journal of Geoscience and Environment Protection, 4, 33-42. 
1) Sanitary Landfills (SLF) are engineered sites where environment problems are minimized by a daily programme of spreading the received wastes in layers followed by compacting and then covering them with soils.

2) Secured Landfills are like sanitary SLF but are constructed such that there is no hydraulic connection between the wastes, leachate and natural waters.

3) Modern Landfills are well engineered facilities that are properly located, designed, operated, monitored and closed according to well defined procedures. Monitoring continues even after closure. They are cleaned when necessary and are fenced to ensure compliance with government regulations to protect human health, environment and groundwater resources.

In Nigeria, open dumping of wastes on any available land space is a common method of solid waste disposal by urban dwellers despite the pollution associated with this method compared to the environment friendly waste management techniques of waste avoidance, source reduction, reuse and recycling. The open dumps have their inherent disadvantages but a more serious long term threat is the production of leachate from chemical and biological processes that break down wastes. When water comes in contact with wastes at a dump site, a foul smelling noxious liquid called leachate is produced which may contain toxic materials leached from the wastes. Once spilled in the ground, these contaminants migrate downward through the underlying strata under gravity and capillarity. This movement is enhanced by many processes including molecular diffusion, advection/convection, and mechanical dispersion. Physical, chemical and biological interactions in the subsurface by soil and leachate may ultimately pollute the environment. This implies that potential adverse, long term and irreversible impacts may occur in groundwater systems since the chemical composition of the leachate may exceed permissible limits. In landfill construction, site selection is important because the biophysical conditions of the subsoil (stratification and type) and geohydrologic parameters (aquifer type, depth to water table, flow directions) must be demonstrated to conform to local requirements for environmental protection. Despite advances in landfill construction technology, long term impact on the structural competence of the site by composite geologic, chemical and biological characteristics of both soil and water are always factored into landfill design, thus a thorough investigation of a proposed landfill site is often carried out before construction [1]-[4].

Soils play an important role in groundwater protection and in the transport and fate of the contaminants. The movement and attenuation of contaminants in the subsurface environment depend on several geological, chemical and biological factors including the site geology, thickness of the vadose zone, groundwater flow direction and velocity, aquifer hydraulic properties and quality and abstraction of surface and groundwater. The site in the Niger Delta area of Southern Nigeria where a sanitary landfill is proposed to be constructed is a wetland with potentials for severe environmental impacts. The mean annual rainfall exceeds $2000 \mathrm{~mm}$. Groundwater tables are often very close to the surface. Thus landfills with potentials to cause pollution need to be planned, designed, constructed, operated and maintained according to best practice [5]-[10].

Three kinds of studies are important of proposed landfill sites. First, the geohydrolological integrity of a site must be ascertained to ensure that it is stable and ground water friendly. Geotechnical and hydrogeological data required at landfill sites include, bulk density of the soils, discontinuities, hydrogeological characteristics of vadose and soil and water geochemistry [11] [12]. Secondly, biological and chemical studies of the vadose zone are important to assess the natural attenuation capacity of the soils in the event of leakages from the facility into surrounding soils. Finally, the transport and fate of contaminants at the site are always modelled to predict the pathways and receptors of the contaminants over a period of time if pollution occurs. This evaluation of the complex site biophysical factors that control the transformation of waste to the final state is critical to the safe construction of sanitary landfill to ensure that soil and groundwater is protected from contamination from leachate and surface runoff [13]. The important site parameters that significantly influence the occurrence of natural attenuation can be subdivided into geological (hydrogeological), chemical and biological characteristics. In a previous study, [14] used only biological characteristics of soils to assess natural attenuation in the landfill site proposed as an integrated waste management facility for use in the disposal of general refuse and pre-treated hazardous material. The present study evaluates the subsurface biophysical conditions of soils and groundwater in the vadose zone as composite factors in the assessment of the parameters favourable to the potential occurrence and natural attenuation capacity at the site by using geological and chemical characteristics.

\section{Study Area Description}

The landfill site is located $15 \mathrm{~km}$ north of Port Harcourt in southern Nigeria. Vegetation is characteristically rainforest with very tall trees. The area is drained by the Otamiri River which lies about $4 \mathrm{~km}$ to the west of the 
proposed facility site which is also the local groundwater flow direction. Geologically, the site is part of the Tertiary Niger Delta. The local rock cover consists essentially of the Benin Formation which is predominantly sandy with a few shale intercalations. The sand and sandstones are coarse-grained and constitute the main regional aquifer. The location of the site and an outline of the landfill geometry are shown in Figure 1.

\section{Materials and Methods}

The study was undertaken towards the end of the wet season (October-November). Ten environmental boreholes, each $20 \mathrm{~m}$ deep, were drilled by the percussion method at strategic locations across the proposed integrated waste management facility as shown in Figure 1. Borehole 1 was specifically located slightly outside the study area at the up-gradient section of the project area to also serve as a control while boreholes 9 and 10 were located in the down-gradient to serve as monitoring observation wells. The wells were completed with $5 \mathrm{~cm}$ diameter PVC casing and screens. The annulus of the boreholes was backfilled with uniformly graded coarse sand up to $0.5 \mathrm{~m}$ above screen level. Well cuttings were used to backfill the remaining part of the annulus up to 0.75 $\mathrm{m}$ below ground surface and finally cement grouted to the surface, ensuring that the cement grout completely sealed the casing in order to prevent the introduction of surface contaminants into the aquifer. The wells were then developed and thereafter, water levels were allowed to stabilize for one week following which the static water levels were measured using a Fisher Model electric water level indicator before water samples were collected for analysis. To avoid contamination by drilling chemicals, soil samples for moisture content, physico-chemical properties and microbiological studies were collected at $0.5 \mathrm{~m}$ intervals from $3 \mathrm{~m}$ auger holes located beside each of the 10 boreholes. Undisturbed samples for bulk density determination were taken in a $50 \mathrm{~m}$ grid at the depth of $150-400 \mathrm{~mm}$. In the laboratory, the geotechnical index properties of the soils including particle size distribution, bulk density, permeability, Atterberg limits, and porosity were determined as specified in [15]. Soil nutrients including $\mathrm{pH}$, Organic matter, $\mathrm{PO}_{4}^{2+}, \mathrm{SO}_{4}^{2+}, \mathrm{Ca}^{2+} \mathrm{Mg}^{2+}, \mathrm{NO}_{3}^{-}, \mathrm{NH}_{4+}, \mathrm{NO}_{2}^{-}$and $\mathrm{K}^{+}$were determined using standard [16] methods, as well as heavy metals, total organic hydrocarbon and oil and grease. Total organic carbon and total organic nitrogen of soil were determined using Walkley-Black and Macro-Kjeldahl methods respectively. Soil pH was determined using PYE UNICAM PW $9418 \mathrm{pH}$ meter fitted with a combined glass $\mathrm{pH}$ and reference electrode. Soil moisture content was determined by evaporation on Whatman filter paper No. 1 at $103^{\circ} \mathrm{C}$ in an electrical oven.

The attenuation capacity of the vadose zone was evaluated using microbial degradation test of some major constituents of the leachate including fatty acids, organic nitrogen and chloride for a 28-day period. Olive oil served as source of fatty acid. Soil mixed with mercury chloride was used as negative control while surface soil

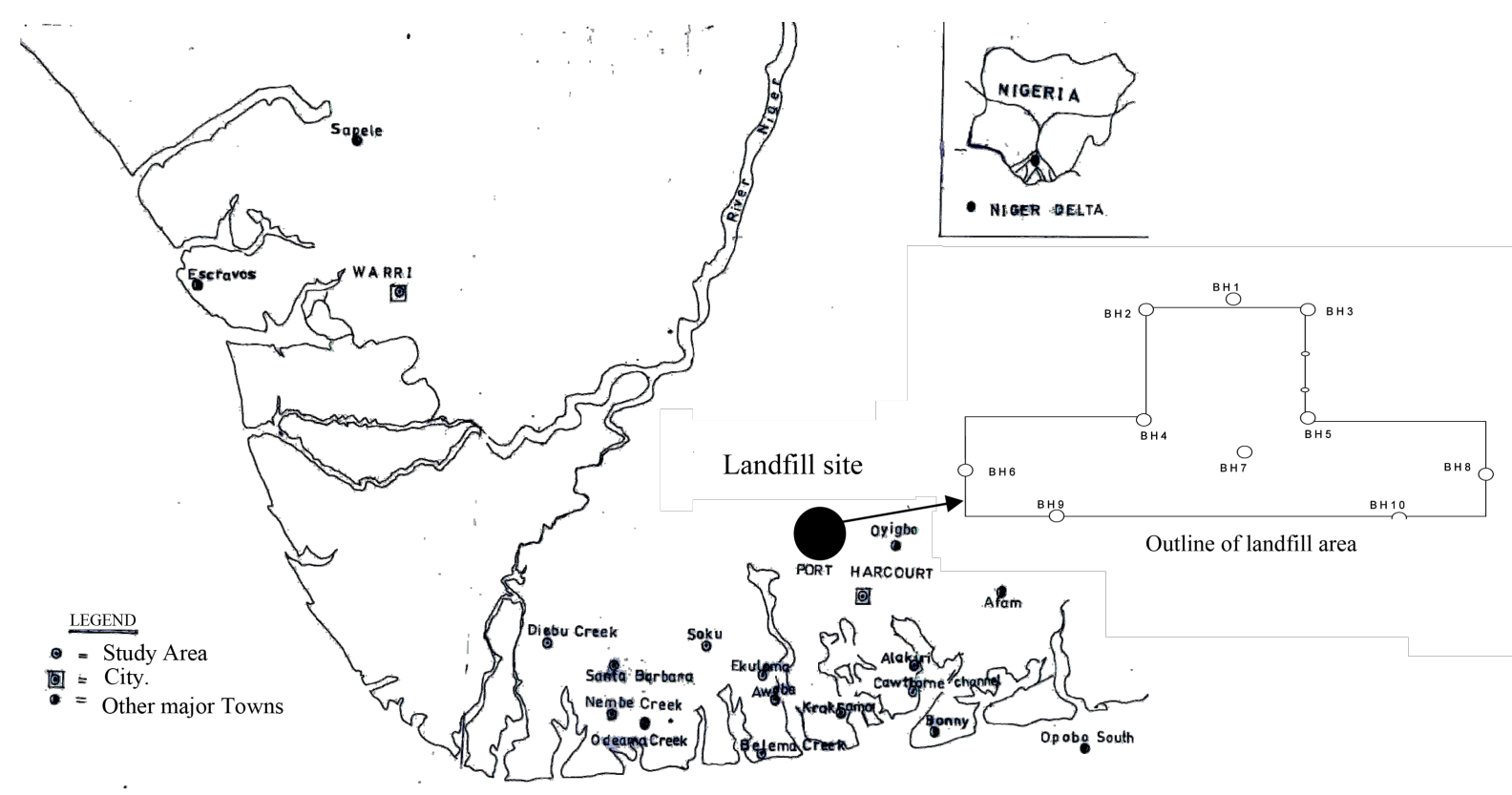

Figure 1. Map of the Niger Delta showing landfill site and its outline. 
(0 - $15 \mathrm{~cm}$ depth) from the same area was used as control. Two concentrations of olive oil, ammonium sulphate and sodium chloride which served as sources of organic carbon, nitrogen and chloride respectively were used to simulate anticipated leachate from the facility. The objective of the experimental design was to simulate leachate concentrations of fatty acids, chloride and ammonium nitrogen that were similar to the anticipated leachate concentrations during the dry and wet seasons. Ten treatment options in triplicate were employed as follows:

Option 1, 2, 3, 4 had concentration of $\left(\mathrm{NH}_{4}\right)_{2} \mathrm{SO}_{4}$ (olive oil) that were of dry season value.

Options 5, 6, 7, and 8 had concentration of olive oil that were of wet season value

Options 2, 4, 5, and 8 had concentration of $\left(\mathrm{NH}_{4}\right)_{2} \mathrm{SO}_{4}$ that were of dry season value

Options 1, 3, 6, and 7 had concentrations of $\left(\mathrm{NH}_{4}\right)_{2} \mathrm{SO}_{4}$ that were of wet season value

Options 3, 4, 7 and 8 had concentration of $\mathrm{NaCl}$ that were of dry season value while

Options 1, 2, 5, and 6 had concentration of $\mathrm{NaCl}$ that were of wet season value

Options 4 and 6 were representative of leachate during dry and wet season respectively.

Options 1, 2, 3, 5, 7 and 8 were mixed.

Option 9 was the negative control which contained olive oil and mercury chloride poison to kill bacteria.

Option 10 was the control sample which contained dry season levels of olive oil $\left(\mathrm{NH}_{4}\right)_{2} \mathrm{SO}_{4}$ and $\mathrm{NaCl}$ in top soil (0 - $15 \mathrm{~cm}$ depth) which is expected to contain more bacteria than the deeper soil. The total heterotrophic bacteria (THB) count of soil samples was performed by inoculating $0.1 \mathrm{ml}$ of appropriate dilution of soil suspension in deionized water on nutrient agar plates using the spread plate technique [17].

Higher concentrations of constituents in the 10 options represented dry season levels, while the lower concentrations represented the wet season levels. Each option was placed in a dark plastic container of $1.5 \mathrm{~L}$ volume biodegradation test vessel and then kept in a thermos cooler which contained a lit candle to eliminate most of the air for the 28-day duration of the study. The candle light was extinguished after 3 hours as a result of depletion of oxygen level with the exception of option 10. The objective of this low oxygen incubation at room temperature was to simulate microaerophilic to anaerobic condition in the soil (at depth $6.5 \mathrm{~m}$ ) where low levels of oxygen are characteristic. The options were watered every 7 days with $25 \mathrm{ml}$ of distilled water to maintain a fairly constant moisture content of soil in all the options. Analysis of soil physicochemical properties and total heterotrophic bacteria count was performed on surface and $6.5 \mathrm{~m}$ deep soils before and after treatment with simulated leachate on day $0,7,14,21$, and 28 . The physical and chemical characteristics of the soils before treatment are shown in Table 1. Qualitative evaluation of the attenuation capacity involved the overall assessment of the site

Table 1. Physical properties of soil before treatment.

\begin{tabular}{ccc}
\hline Parameters & \multicolumn{2}{c}{ Soil samples } \\
\hline Description & $(0-15 \mathrm{~cm}$ depth $)$ & $(6.5 \mathrm{~m}$ depth $)$ \\
\cline { 2 - 3 } Porosity & Darkish top soil & Brownish clayey soil \\
\hline Bulk density $\left(\mathrm{kg} / \mathrm{m}^{3}\right)$ & 0.38 & 0.38 \\
Permeability $(\mathrm{cm} / \mathrm{sec})$ & 1750 & 1890 \\
Sand & $3.6 \times 10^{-5}$ & 0.0144 \\
Silt & $75 \%$ & $75 \%$ \\
Clay & $20 \%$ & $20 \%$ \\
pH & $5 \%$ & $5 \%$ \\
\% Moisture & $6.65 \pm 0.03$ & $6.2 \pm 0.2$ \\
\% Total Organic Carbon & $14.4 \pm 0.5$ & $10.7 \pm 0.03$ \\
\% Organic Nitrogen & $0.58 \pm 0.04$ & $0.18 \pm 0.02$ \\
\% Ammonium Nitrogen & $0.105 \pm 0.02$ & $0.0035 \pm 0.0001$ \\
Chloride (mg/g) & $0.02 \pm 0.01$ & $0.0014 \pm 0.0001$ \\
Sulphate (mg/g) & $780 \pm 10.5$ & $750 \pm 0.5$ \\
Phosphate (mg/g) & $120 \pm 5.0$ & $71.4 \pm 2.5$ \\
\hline
\end{tabular}


conditions using hydrogeological, chemical and biological characteristics which are considered as important site parameters that influence the occurrence of natural attenuation.

\section{Results}

The stratigraphy of the area delineated from soil samples obtained in the $20 \mathrm{~m}$ deep boreholes is characterized by three major soil types: a 1-m thick top darkish clayey fine sand underlain by a 10-m thick brownish clayey sand which is in turn succeeded by a 9-m thick fine to coarse sand horizon. The characteristics of the various horizons are presented in the Table 2. At the time of the investigation in October which is about the end of the rainy season, the depth to water table which is equal to the thickness of the vadose zone varied from $8-13 \mathrm{~m}$. The groundwater flows in a westerly direction towards the Otamiri River with a hydraulic gradient of approximately $4.0 \times 10^{-3}$ (or $0.4 \%$ ). Since the average hydraulic conductivity of the aquifer is $3.5 \times 10^{-3} \mathrm{~cm} / \mathrm{sec}$ and the effective porosity is $0.45 \%$, the pore velocity of the groundwater is therefore equal to $1.6 \times 10^{-3} \mathrm{~cm} / \mathrm{sec}$. The [18] which regulates environmental guidelines and standards for the petroleum industry in Nigeria specifies that the top of a landfill should be at least $1.5 \mathrm{~m}$ below the land surface and the bottom should be $1.5 \mathrm{~m}$ above the water table. When these depths $(1.5 \mathrm{~m}+1.5 \mathrm{~m})$ are added to the proposed $5 \mathrm{~m}$ thickness of the landfill, the minimum thickness of the vadose zone that is required is $8 \mathrm{~m}$ which is therefore adequate at this location. The presence of clay minerals will decrease not only the permeability of the soil but also its absorptive capacity. The depth to the water table and the clayey nature of the soil implies that downward migration of contaminants may be hindered in the vadose zone. On contact with groundwater however, the pollution plume and dissolved phases will move in the direction of the groundwater flow by advection.

The groundwater chemistry is shown in Table 3 . The groundwater is slightly basic in nature with $\mathrm{pH}$ values ranging from 6.97 to 7.25. Only water in $\mathrm{BH} 6$ and $\mathrm{BH} 9$ exhibited $\mathrm{pH}$ values that were below 7.0. The conductivity values range from $80.2 \mu \mathrm{S} / \mathrm{cm}$ to $287.0 \mu \mathrm{S} / \mathrm{cm}$ indicating low ionic content of the groundwater. Sulphate ions ranged from $0.02-0.62 \mathrm{mg} / \mathrm{l}$. The concentrations of nitrate and phosphate are much lower than that of sulphate. Most of these parameters are within the [19] limits for potable water.

Table 2. Index properties of the various soil layers.

\begin{tabular}{|c|c|c|c|c|c|c|c|c|c|}
\hline Layer & $\begin{array}{l}\text { Depth } \\
\text { (m) }\end{array}$ & Description & $\begin{array}{c}\text { Texture/percentage } \\
\text { composition }\end{array}$ & $\begin{array}{l}\text { Uniformity } \\
\text { coefficient }\end{array}$ & $\begin{array}{l}\text { Permeability } \\
\text { (cm/sec) }\end{array}$ & $\begin{array}{c}\text { Liquid } \\
\text { Limit (\%) }\end{array}$ & $\begin{array}{l}\text { Plastic Limit } \\
\text { (\%) }\end{array}$ & $\begin{array}{l}\text { Plasticity } \\
\text { index }\end{array}$ & $\begin{array}{c}\text { Natural } \\
\text { Moisture } \\
\text { content (\%) }\end{array}$ \\
\hline I & $0-0.5$ & $\begin{array}{l}\text { clayey fine } \\
\text { sand) }\end{array}$ & $\begin{array}{c}\text { Sand }(65 \%-76 \%) \\
\text { Silt \& clay } \\
(24 \%-35 \%)\end{array}$ & - & $10^{-5}$ & $34-45$ & $17-21$ & $17-24$ & $14-35$ \\
\hline II & $0.5-11$ & $\begin{array}{l}\text { Brownish } \\
\text { clayey sand }\end{array}$ & $\begin{array}{c}\text { Sand }(75 \%-96 \%) \\
\text { Silt \& clay }(4 \%-25 \%)\end{array}$ & 4 & $10^{-3}-10^{-4}$ & $40-44$ & $21-22$ & $19-22$ & $15-37$ \\
\hline III & $11-20$ & $\begin{array}{l}\text { fine-coarse } \\
\text { Sand }\end{array}$ & $\begin{array}{l}\text { Sand }(99 \%-100 \%) \\
\text { Silt \& clay }(0 \%-1 \%)\end{array}$ & $4-6$ & $10^{-2}-10^{-3}$ & $33-40$ & $15-18$ & $16-22$ & $12-22$ \\
\hline
\end{tabular}

Table 3. Physico-chemical characteristics of groundwater.

\begin{tabular}{|c|c|c|c|c|c|c|c|c|c|c|c|c|c|}
\hline BH No & $\mathrm{p}^{\mathrm{H}}$ & $\begin{array}{l}\text { Cond. } \\
\text { ( } \mu \mathrm{s} / \mathrm{cm})\end{array}$ & $\begin{array}{c}\text { TDS } \\
(\mathrm{mg} / 1)\end{array}$ & DO mg/1 & Temp ${ }^{\circ} \mathrm{C}$ & $\begin{array}{c}\text { TSS } \\
\mathrm{mg} / 1\end{array}$ & $\begin{array}{c}\text { BOD } \\
(\mathrm{mg} / 1)\end{array}$ & $\begin{array}{c}\text { Turbidity } \\
\text { (NTU) }\end{array}$ & $\begin{array}{l}\text { Hardn } \\
(\mathrm{mg} / 1)\end{array}$ & $\begin{array}{c}\mathrm{Cl}^{-} \\
\mathrm{mg} / 1\end{array}$ & $\begin{array}{l}\mathrm{SO}_{4}^{2-} \\
\mathrm{mg} / 1\end{array}$ & $\begin{array}{l}\mathrm{NO}_{3}^{-} \\
\mathrm{mg} / 1\end{array}$ & $\begin{array}{l}\mathrm{PO}_{3}^{4-} \\
\mathrm{mg} / 1\end{array}$ \\
\hline BH1 & 7.11 & 287 & 142 & 4.8 & 28 & 650 & 15 & 1.60 & 65 & 4.5 & 0.02 & 0.09 & 0.06 \\
\hline ВН3 & 7.11 & 80.2 & 42.4 & 5.6 & 28 & 7.30 & 50 & 2.30 & 95 & 3.0 & 0.04 & 0.04 & 0.03 \\
\hline $\mathrm{BH} 4$ & 7.17 & 119.7 & 55.8 & 5.5 & 27.5 & 15.60 & 70 & 3.5 & 75 & 4.0 & 0.62 & 0.07 & 0.05 \\
\hline BH5 & 6.99 & 282 & 140 & 4.8 & 28 & 460 & 180 & 2.8 & 80 & 5.0 & 0.06 & 0.10 & 0.07 \\
\hline BH6 & 7.25 & 125.9 & 62.9 & 5.3 & 28.5 & 10.40 & 65 & 3.2 & 85 & 4.5 & 0.06 & 0.08 & 0.05 \\
\hline BH8 & 6.97 & 185.8 & 93.0 & 5.2 & 27.5 & 20.80 & 190 & 2.6 & 255 & 3.5 & 0.04 & 0.06 & 0.0 .07 \\
\hline BH9 & 7.13 & 84.6 & 42.1 & 5.8 & 28.0 & 12.20 & 150 & 2.6 & 55 & 23.8 & 0.04 & 0.05 & 0.04 \\
\hline BH10 & 7.04 & 115.6 & 57.9 & 5.4 & 27.5 & 5.63 & 75 & 3.0 & 75 & 3.5 & 0.04 & 0.08 & 0.06 \\
\hline
\end{tabular}


The mean microbial count in the soil is summarized in Table 4. The geological and chemical data were integrated with biological characteristics used by [14] to evaluate the natural attenuation potentials of the vadose.

\section{Discussion of Biodegradation Results}

The percentage reduction in the various properties with time during the degradation period is presented in Figure 2 and the overall results summarized in Table 5. The reductions in the contents of the various components including ammonia nitrogen, organic nitrogen, chloride, sulphate and phosphate indicate that they were utilized during the biodegradation process. Relatively smaller reductions in the chloride and sulphate concentrations indicate they are less significant in the biodegradation process compared to ammonia nitrogen, organic nitrogen, and phosphate. pH declined progressively in all treatment options (except option 9) due to the microaerophilic and anaerobic degradation of olive oil into fatty acids. The fatty acid may have accentuated the lowering of the $\mathrm{pH}$. Where the conditions were mainly aerobic and microaerophilic as obtained in option 10, the degradation of olive oil first gave rise to fatty acids before complete mineralization occurred in the presence of oxygen. In the dry season (option 4), the $\mathrm{pH}$ is lower because there were higher concentrations of olive oil, $\left(\mathrm{NH}_{4}\right)_{2} \mathrm{SO}_{4}$ and $\mathrm{NaCl}$ compared to the wet season.

Ammonium nitrogen and organic nitrogen decreased steadily in all the options except option 9) due to microbial utilization of nitrogen [20] [21]. Organic nitrogen utilization was greater in the dry than wet season implying that the rate of organic nitrogen increased with high concentrations of utilizable nitrogen source. In the field, the availability of utilizable nitrogen source in a leachate is higher in the dry season than in the wet season when dilution occurs. The seasonal differences in the contents of the other components may similarly be explained by

Table 4. Mean microbial count of soil samples.

\begin{tabular}{cccccc}
\hline & & \multicolumn{3}{c}{ Mean Microbial count (cfu/g. or ml. of sample) } \\
\cline { 3 - 5 } S/No & Sample Description & Heterotrophic & Fungal & Coliform & Hydrocarbon \\
\cline { 3 - 5 } & & count & count & count & degraders \\
\hline 1. & Surface (Soil, $0-15 \mathrm{~cm}$ ) & $8.30 \times 10^{5}$ & $1.44 \times 10^{4}$ & $<\times 10^{3}$ & $3.7 \times 10^{4}$ \\
2. & Subsurface (Soil, 0.5 m) & $3.86 \times 10^{4}$ & $2.13 \times 10^{3}$ & $<\times 10^{3}$ & $1.0 \times 10^{3}$ \\
3. & Subsurface (Soil, $1.0 \mathrm{~m})$ & $5.87 \times 10^{3}$ & $<\times 10^{3}$ & $<\times 10^{3}$ & $1 \times 10^{3}$ \\
4. & Subsurface (Soil, $1.5-3 \mathrm{~m})$ & $1 \times 10^{3}$ & $<\times 10^{3}$ & $<\times 10^{3}$ & $1 \times 10^{3}$ \\
5. & Subsurface (aquifer mud) & $4.80 \times 10^{5}$ & $8.53 \times 10^{3}$ & $<\times 10^{3}$ & $1.08 \times 10^{4}$ \\
6. & Subsurface (aquifer water) & $4.78 \times 10^{3}$ & $\times 10^{3}$ & $<\times 10^{3}$ & $1 \times 10^{3}$ \\
\hline
\end{tabular}

Table 5. Percent reduction in soil parameters during degradation period.

\begin{tabular}{|c|c|c|c|c|c|c|c|c|}
\hline \multirow[b]{3}{*}{ Week } & \multicolumn{4}{|c|}{ Dry season samples } & \multicolumn{4}{|c|}{ Wet season samples } \\
\hline & \multicolumn{4}{|c|}{ \% reduction from weeks 1 to 4} & \multicolumn{4}{|c|}{ \% reduction from weeks 1 to 4} \\
\hline & 1 & 2 & 3 & 4 & 1 & 2 & 3 & 4 \\
\hline $\mathrm{PH}$ & 3 & 8 & 8 & 8 & 2 & 2 & 3 & 4 \\
\hline Soil moisture & 10 & & 10 & & 10 & 10 & 10 & \\
\hline Ammonia Nitrogen & 29 & 63 & 82 & 100 & 26 & 66 & 84 & 100 \\
\hline Organic nitrogen & 26 & 48 & 75 & 97 & 17 & 26 & 30 & 41 \\
\hline Chloride & 5 & 5 & 5 & 52 & 0 & 0 & 0 & 20 \\
\hline Phosphate & 57 & 87 & 92 & 95 & 30 & 55 & 80 & 100 \\
\hline Sulphate & 16 & 35 & 44 & 50 & 3 & 7 & 6 & 7 \\
\hline Organic carbon & 49 & 94 & 95 & 95 & 50 & 99 & 100 & 100 \\
\hline THB (increase) & 900 & 2100 & 20,900 & 79,900 & 1500 & 3900 & 15,900 & 74,900 \\
\hline
\end{tabular}



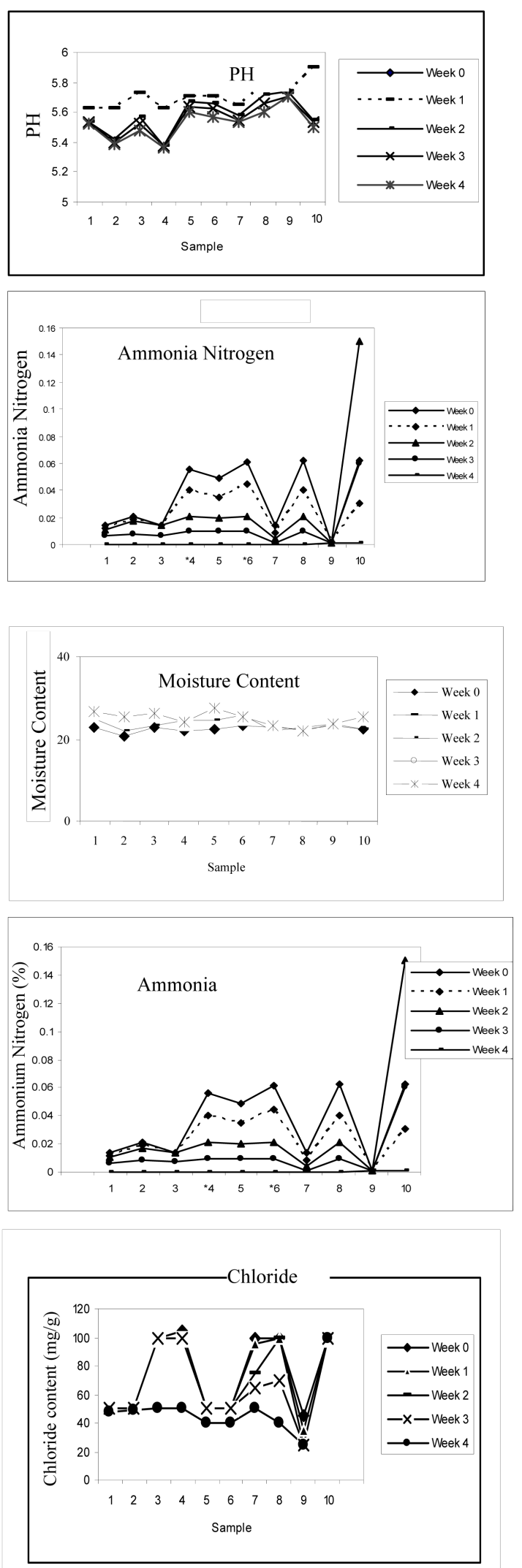
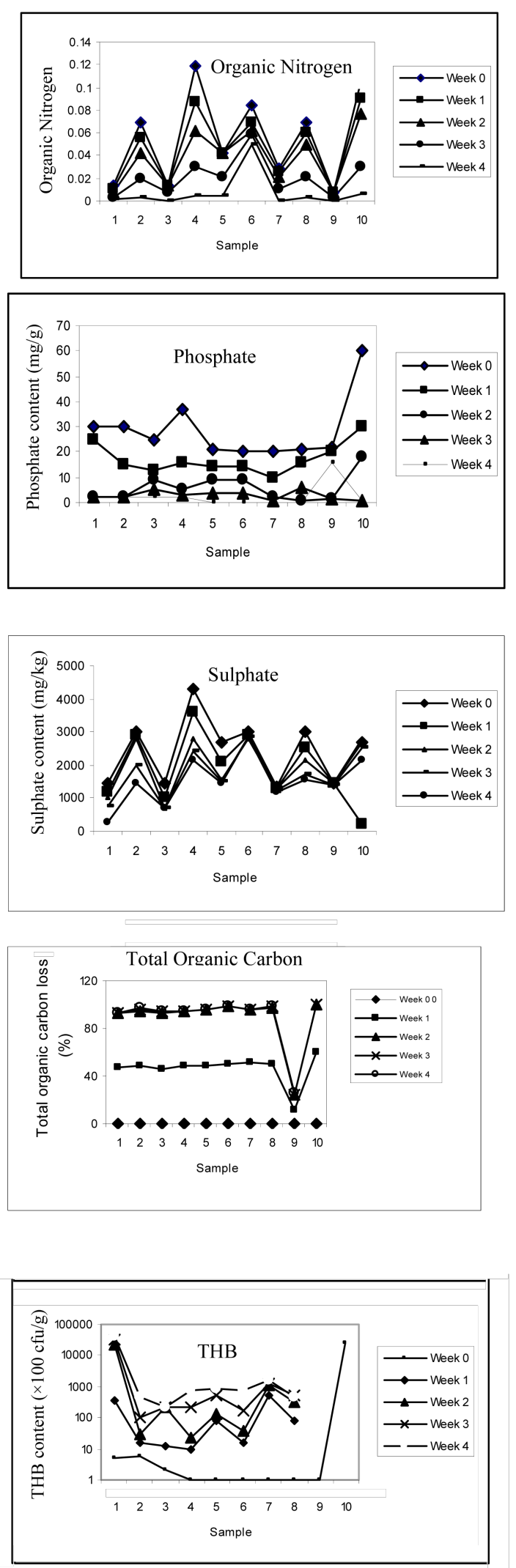

Figure 2. Changes in the components of the soil during degradation period. 
this phenomenon. Two concentrations of $\mathrm{NaCl}(0.5 \mathrm{~g} / \mathrm{kg}$ and $1.5 \mathrm{~g} / \mathrm{kg}$ of soil $)$ were employed in this study. Results revealed that the higher concentration of $\mathrm{NaCl}$ promoted disappearance of chloride. Other than option 9, all other options recorded significant percentage organic carbon removal at day 14 . However, the removal stabilized by day 28. The inference from these results is that olive oil, the source of organic carbon was easily biodegraded in the vadose zone. The total heterotrophic bacterial count of all the options except 9 shows an increase with time. The results suggest that the population of aerobic bacteria at soil depth $6 \mathrm{~m}$ is sufficient to bring about over $90 \%$ organic carbon removal. Biodegradation will however be faster in surface soils where aerobic bacteria predominate and oxygen is more readily available to the resident bacterial flora. The general trend of other results indicates that the values of most components analysed declined steadily except moisture content and Total Hetrerotrophic Bacteria count which showed increased values. The decrease in chloride and sulphate are much smaller than the other components. A summary of the qualitative assessment of the various site specific characteristics that favour natural attenuation is shown in Table 6 . The reduction in the values of properties in the dry season is greater than in the wet season although the seasonal differences vary within very narrow ranges. The results also show that with appropriate physicochemical properties such as the presence of biodegradable organic carbon, the availability of a nitrogen source, etc., biodegradation can take place even in deep soils (6 m deep) under limited oxygen supply. The population of resident heterotrophic bacterial flora in the subsurface soil is also much smaller than in surface soil. Microorganisms in such subsurface environments degrade organic substances slowly when compared to the surface environments [22]. At the proposed landfill site, the leachate degradation in the vadose zone and below is expected to be slow as a result of little oxygen. However, the anaerobic and microaerophilic anaerobic bacteria in the soil at this depth will facilitate the biodegrading process.

\section{Summary and Conclusion}

The results of this study may be summarized as follows:

1) The soils of the vadose zone $(0.5-6.5 \mathrm{~m})$ at the landfill site are mainly brownish clayey sands of low permeability. $\mathrm{pH}$ of the groundwater implies that it is basic in nature.

2) The population of aerobic bacteria within the zone is sufficient to bring about over $90 \%$ organic carbon removal.

3) The major constituents of the leachate such as ammonia/organic nitrogen, phosphate and organic carbon were completely degraded within 28 days while less than $50 \%$ of sulphate and chloride were degraded within the same period.

4) Although the decrease in the components of the leachate is generally higher in the dry season than in the wet season, the seasonal variations are quite insignificant.

Table 6. Qualitative assessment of the attenuation capacity of the site.

\begin{tabular}{|c|c|c|c|}
\hline Parameter & site conditions & $\begin{array}{c}\text { Values/conditions favourable for } \\
\text { natural attenuation }\end{array}$ & $\begin{array}{c}\text { Ranking } \\
\text { (natural } \\
\text { attenuation) }\end{array}$ \\
\hline Soil Permeability & $\begin{array}{c}\text { Sands; } \\
\mathrm{K}=10^{-2}-10^{-4} \mathrm{~cm} / \mathrm{sec}\end{array}$ & $\begin{array}{l}\text { Moderate to high } \\
\text { (i.e. sands, gravels,) } \mathrm{K}>10^{-4} \mathrm{~cm} / \mathrm{sec}\end{array}$ & Favourable \\
\hline Groundwater gradient & $0.4 \%$ & Low to moderate & Favourable \\
\hline $\begin{array}{l}\text { Depth to groundwater } \\
\text { (thickness of vadose zone) }\end{array}$ & $>8 \mathrm{~m}$ & Moderate to deep & Favourable \\
\hline Recharge & $\begin{array}{l}\text { Mean annual rainfall }=2500 \mathrm{~m} \text {; } \\
\text { recharge rate }=0.83 \mathrm{~m} / \mathrm{yr}\end{array}$ & High & Favourable \\
\hline Moisture content & $12 \%-35 \%$ & $\begin{array}{c}\text { Moderate } \\
\text { (avoid excessively wet or dry soil) }\end{array}$ & Favourable \\
\hline Dissolved oxygen (DO) & $4.8-5.8 \mathrm{mg} / \mathrm{l}$ & Minimum is 1 - $2 \mathrm{mg} / \mathrm{l}$ & Favourable \\
\hline Soil/water PH & $6.97-7.13$ & $6-8$ & Favourable \\
\hline Total Heterotrophic (TH) & $1 \times 10^{4}-8.3 \times 10^{5}$ & - & Favourable \\
\hline Hydrocarbon Degraders (HD) & $3 \times 10^{4}-1 \times 19^{3}$ & $>1 \times 10^{5}$ & Favourable \\
\hline Ratio of TH/HD & $20 \%-60 \%$ & $\begin{array}{l}\text { HD is significant } \\
\text { percentage of } \mathrm{TH}\end{array}$ & $\begin{array}{c}\text { Slightly } \\
\text { Favourable }\end{array}$ \\
\hline
\end{tabular}


Results of the assessment of the various site specific characteristics reveal that both hydrogeological and chemical conditions are very favorable for natural attenuation while the in-situ biological conditions appear to be less favourable. The overall site conditions strongly indicate that the potential natural attenuation capacity of the vadose zone is moderate to high.

\section{References}

[1] Leton, T.G. and Omotosho, O.O. (2004) Landfill Operations in the Niger Delta Region of Nigeria. Engineering Geology, 73, 171-177. http://dx.doi.org/10.1016/j.enggeo.2003.12.006

[2] Omar, A. and Abu-Qdais, H. (2006) Municipal Solid Waste Siting Using Intelligent System. Waste Management, 26, 299-306. http://dx.doi.org/10.1016/j.wasman.2005.01.026

[3] Wang, G., Qin, L., Li, G. and Chen, L. (2009) Landfill Site Selection Using Spatial Information Technologies and AHP: A Case Study in Beijing, China. Journal of Environmental Management, 90, 2414-2421. http://dx.doi.org/10.1016/j.jenvman.2008.12.008

[4] Ige, O.O. (2013) Geologic and Geotechnical Evaluation of an Open Landfill for Sanitary Landfill Construction in Ilorin, Southwestern Nigeria. Journal of Environment and Earth Science, 3, 9-17.

[5] Lin, H. and Kao, J. (1999) Enhanced Spatial Model for Landfill Siting Analysis. Journal of Environmental Engineering, 125, 845-851. http://dx.doi.org/10.1061/(ASCE)0733-9372(1999)125:9(845)

[6] Allen, A. (2001) Containment Landfills: The Myth of Sustainability. Engineering Geology, 60, 3-19. http://dx.doi.org/10.1016/S0013-7952(00)00084-3

[7] Hyun, P., Borinara, P. and Hong, K.D. (2011) Geotechnical Considerations for End-Use of Old Municipal Solid Waste Landfills. International Journal of Environmental Research, 5, 573-584.

[8] Nagarajan, R., Thirumalaisamy, S. and Lakshumanan, E. (2012) Impact of Leachate on Groundwater Pollution Due to Non-Engineered Municipal Solid Waste Landfill Sites of Erode City, Tamil Nadu, India. Iranian Journal of Environmental Health Science \& Engineering, 9, 35. http://dx.doi.org/10.1186/1735-2746-9-35

[9] Abdelwaheb, A., Zairi, M. and Ben Dhia, H. (2013) Minimization of Environmental Risk of Landfill Site Using Fuzzy Logic, Analytical Hierarchy Process and Weighted Linear Combination Methodology in a Geographic Information System Environment. Environmental Earth Sciences, 68, 1375-1389. http://dx.doi.org/10.1007/s12665-012-1836-3

[10] Dong, W., Zhang, Y., Lin, X. and Du, S. (2014) Prediction of 1,2,4-Trichlorobenzene Natural Attenuation in Groundwater at a Landfill in Kaifeng, China. Environmental Earth Sciences, 72, 941-948. http://dx.doi.org/10.1007/s12665-014-3386-3

[11] Yildirim, M. (1997) Engineering Geological Evaluation of Solid Waste Landfill Sites: Two Examples from Istanbul, Turkey. Bulletin of Engineering Geology and Environment, 55, 151-158. http://dx.doi.org/10.1007/BF02635417

[12] Adeyemi, G.O. and Oyediran, I.A. (2005) Engineering Geological Evaluation of a proposed Landfill Site at Aba-Kulodi, Near Ibadan, Southwestern Nigeria. Global Journal of Geological Sciences, 3, 25-33.

http://dx.doi.org/10.4314/gjgs.v3i1.18707

[13] Koliopoulos, T., Kollias, V., Koliopoulu, G. and Kollias, S. (2007) Geotechnical and Environmental Aspects of Waste Disposal Sites. In: Sarsby, R.W. and Felton, A.J., Eds., Proceedings and Monographs in Engineering, Water and Earth Sciences, Taylor and Francis Group, London, 49-57.

[14] Odokuma, L.O. and Akpokodje E.G. (2004) Biodegradation of a Simulated Leachate landfill in Tropical Soils of Depth 6.5m. Journal of Applied Science, Engineering and Technology, 4, 6-14.

[15] British Standard Institution 1377 (1990) Methods of Test for Soil for Civil Engineering Purposes. BS 1377, London.

[16] APHA (American Public Health Association) (1985) Standard Method for the Examination of Water and Waste Water. 16th Edition, Washington DC.

[17] Odokuma, L.O. and Ibor, M.N. (2002) Nitrogen Fixing Bacteria Enhanced Bioremediation of a Crude Oil Polluted Soil. Global Journal of Pure and Applied Sciences, 8, 455-468. http://dx.doi.org/10.4314/gjpas.v8i4.15993

[18] DPR (Department of Petroleum Resources) (2002) Environmental Guidelines and Standards for the Petroleum Industry in Nigeria. Department of Petroleum Resources, Lagos.

[19] WHO (World Health Organisation) (2011) Guidelines for Drinking Water Quality. 4th Edition. http://www.who.int

[20] La Dousse, A., Tallec, C. and Tramcer, B. (1987) Progress in Enhanced Oil Degradation. Proceedings of the 1987 Oil Spill Conference, American Petroleum Institute, Washington DC, Abstract 142.

[21] Ladousse, A. and Tramier, B. (1991) Results of 12 Years of Research in Spilled Oil Bioremediation. International Oil Spill Conference Proceedings, American Petroleum Institute, Washington DC, 577-581. 
http://dx.doi.org/10.7901/2169-3358-1991-1-577

[22] Fredrickson, J.K., Brockman, F.J. and Workman, D.J. (1991) Isolation and Characterization of a Subsurface Bacterium Capable of Growth on Toluene, Naphthalene and other Aromatic Compounds. Applied and Environmental Microbiology, 57, 796-803. 